\title{
Cutting, Driving, Digging, and Harvesting: Re-masculinizing the Working-Class Heroic
}

\author{
Augie Fleras \\ University of Waterloo \\ Shane Michael Dixon \\ Ryerson University
}

\begin{abstract}
Television portrayals of working-class males in blue-collar jobs have in the past proven unflattering at best, demeaning at worst. But a new breed of unscripted TV shows articulates a fundamentally different narrative about the unsung heroism of working-class men. This article explores the narratives and images associated with the re-masculinization of blue-collared working-class males as real men in contrast to conventional working-class misrepresentations as persons lacking self control, motivation and commitment. This genre of "macho" male programs constitutes a key ideological tool by which "hegemonic" narratives of conventional masculinity are internalized through the "pleasures of the media." The authors conclude that, despite the recent valorization of blue-collar values, contributions, and identities, representational distortions and content omissions persist in portraying workingclass realities.
\end{abstract}

\section{KEYWORDS “Docu soaps"; Heroism; Masculinity; Television; Working-class}

RÉSUMÉ La manière dont les médias ont dépeint les hommes de la classe ouvrière dans des emplois de cols bleus a été dans le passé peu flatteuse au mieux et dégradante au pire. Mais un nouveau type d'émission non-scénarisé articule une narration fondamentalement différente qui porte sur l'hérö̈sme méconnu des hommes de la classe ouvrière. Cet article explore les narrations et les images associées à la « remasculinisation » des cols bleus par rapport à la façon dont on les a décrits traditionnellement, à savoir comme des hommes manquant de maîtrise de soi, de motivation et de persévérance. Ce genre de programme sur le mâle macho est un outil idéologique clé par lequel les spectateurs, grâce au " plaisir des médias », internalisent des narrations hégémoniques sur la masculinité conventionnelle. Les auteurs concluent que, malgré la reconnaissance récente des valeurs, contributions et identités des cols bleus, des distorsions représentationnelles et des omissions de contenu persistent dans la manière dont les médias dépeignent la classe ouvrière.

MOTS CLÉS Feuilleton-documentaire; Héroïsme; Masculinité; Télévision; Classe ouvrière

Augie Fleras is Professor in the Department of Sociology at the University of Waterloo, 200 University Avenue West, Waterloo, ON N2L 3G1. Email: fleras@uwaterloo.ca. Shane Michael Dixon is a postdoctoral fellow in the Department of Mechanical and Industrial Engineering at Ryerson University, 350 Victoria Street, Toronto, ON M5B 2K3. Email: shane.dixon@ryerson.ca.

Canadian Journal of Communication Vol 36 (2011) 579-597

(C)2011 Canadian Journal of Communication Corporation 


\section{Introduction: Masculinities in representational disarray}

To say media messages are pivotal in moulding individual attitudes and shaping 1 public discourses is trite yet true. Media messages constitute potent socializing agents of social control whose representations of reality are constructed and conventional rather than a mirroring of the world out there. The constructedness of these conventions as natural and normal is largely hidden from view as part of a tacitly assumed media gaze (Fleras, 2011), but internalized as values, beliefs, and norms without people's awareness that their attitudes are changing. The seemingly apolitical dynamic of this socialization process both exposes and camouflages the hegemonic process by which dominant ideas are internalized through the pleasures of the media rather than through explicit indoctrination (Kellner, 1995). In drawing attention to some aspects of reality as desirable and acceptable, while excluding other dimensions as inferior or irrelevant, media messages may be interpreted as discourses in defence of dominant ideology (Henry \& Tator, 2002).

Nowhere is this hegemony more evident than in media representations of social classes. The combination of media ownership patterns and commercial imperatives, together with institutional values and systemic biases, reinforces patterns of omission or distortion (Hackett \& Gruneau, 2000; Winter, 2001). Although the relationship between class and media is unmistakable, thanks to the intertwining of corporate priorities with class interests in formulating media content, studies rarely address the representational basis of media-working-class relations. The few studies that there are support what many have long suspected: entertainment media tend to under-represent working-class males in domains that count, over-represent them in domains that do not count, and misrepresent them in between by framing ${ }^{1}$ working-class folk as little more than "troublesome constituents."

However accurate this assessment, there is no mistaking the re-emergence of popular television representations that celebrate the heroism of the blue-collar worker. Robust reality-based shows involving hard-working, hard-driving, and hard-living working-class males are proliferating, including Deadliest Catch (Alaskan fishers), Ice Road Truckers (Arctic truck drivers), Sandhogs (miners in New York City), and Ax Men (American loggers). Each of the documentary-style unscripted programs involves different challenges and coping strategies; nevertheless, attention focuses on work that is risky, rugged, and manageable only by those who can think rationally, objectively assess the situation, and perform accordingly (Dummit, 2007). The proliferation of "docu soaps" (Bruce, 2009; Mazzarella, 2008; Meltzer, 2010) embodies a nostalgic valorization of blue-collar working-class values of virility and toughness-strikingly at odds with the blandly effete white-collar culture of the knowledge economy or the emotional labour of feminized service work (Kusz, 2008; Nixon, 2009). In light of the much ballyhooed crisis of masculinity because of global, structural, and cultural changes (Faludi, 1999), these docu soaps on "doing" (digging, harvesting, driving, and cutting) secure a platform for varied discourses about symbolically re-masculinizing working-class males around blue-collar jobs.

The irony is inescapable: As blue-collar jobs drift into oblivion (Kimmel, 2010; Nixon, 2009), there is a spike in reality-based programming that valorizes working- 
class males in testosterone-driven blue-collar work (Carroll, 2008; Malin, 2010). This paradox creates an opportunity to address the representational politics and ideological framing of working-class males in blue-collar jobs (Hutcheon, 2009). By analyzing those docu soaps that focus on hyper-masculine performance of men under duress, this article explores the narratives and images associated with the re-masculinization of blue-collared working-class males as real men. To the extent that this heroic working-class culture is anchored in the "muscular" values of virility, authenticity, autonomy, aggression, and esprit de corps, these shows collectively challenge those narratives that disparaged the working class as "knuckle-dragging Neanderthals." Nevertheless, despite significant shifts in the politics of re-masculinizing working-class males, significant omissions and distortions in portraying working-class realities are shown to persist, thus reinforcing the claim that what media messages omit may be as or even more important than what they include.

This article capitalizes on the televised spectacle as a starting point for analyzing the politics of masculinity in the twenty-first century. In arguing that the re-masculinization of working-class males reflects a reaction to a long-standing emasculation of this class by the entertainment media, we contend that the reframing of working-class males in these docu soaps provides a useful vantage for analyzing the mediated constructions of alternative and hierarchical masculinities (Kimmel, 2010; Mazzarella, 2008). To be sure, the concept of a hegemonic masculinity as a theoretical construct or normative ideal is both precarious and sharply contested (Connell \& Messerschmidt, 2005). The entertainment media may have been dominated by a hegemonic masculinity of active and domineering males who plied their prowess and power to overcome obstacles in the successful achievement of goals (Fiske, 1987; Mulvey, 1975). But this masculinist trope is being challenged and changed in response to ideological shifts and the structural realities of an increasingly "weightless economy." In that the definition of a hegemonic masculinity is neither static nor inevitable (Connell, 2005; Katz, 1999), but constantly under contestation and construction along the lines of whatever patriarchy wants of masculinity at a particular point in time, the concept reinvents itself by doing whatever is necessary to remain hegemonic, even if this reconceptualization entails incorporating more traditional feminine characteristics-from tears to nurturing (Hanke, 1992, 1998b; Mazzarella, 2008; McDowell, 2003). In short, references to masculinity reject any notion of specific and constant ("essentialized") attributes or natural state of being. Nevertheless, while multiple masculinities based on intersecting inequalities may influence male behaviour, the range of masculinities and the relations between them usually revolve around a hegemonic set of ideals that reflects any society's ruling elites (Connell, 2005).

\section{Televising working classes: Over-representations, under- representations, mis-representations}

Negative media portrayals of working-class and blue-collar workers are taken as axiomatic (Butsch, 2003, 2005; Leistyna \& Alper, 2005; Leistyna \& Mollen, 2008; Mantsios, 2001). For media scholars, this negativity reflects both quantity and quality. As Butsch (1992) concluded on the strength of some 300 domestic sitcoms from 1946 to 1990 , working-class families were grossly under-represented compared to their num- 
bers in the general population. From 1955/56 to 1971, not a single working-class sitcom aired, while on TV middle-class families headed by professional/managerial fathers flourished. When rendered visible - and memorable working-class shows included The Honeymooners (1955-56), All in the Family (1971-79), Sanford and Son (1972-77), Roseanne (1988-97), Married with Children (1987-97), The Simpsons (1990 to present), and Laverne and Shirley (1976-83) - the dominant image of the working-class males rarely flattered. Even changes in culture and to the economy did not translate into improved televisual representations of the working class (Butsch, 2005).

To the extent the working class was portrayed, negative representations prevailed as a major theme (e.g., Aguiar, 2005; Benson, 2005; Butsch, 2005; Croteau \& Hoynes, 2003; Kendall, 2005; Leistyna \& Alper, 2005; Leistyna \& Mollen, 2008; Mantsios, 2001). According to most media scholars, images of working-class males in blue-collar jobs tilted toward trashy (loud, stupid, and often overweight), immature, and irresponsible (thus requiring supervision by their betters). They were portrayed as deviants who must lie and cheat to compensate for personal shortcomings, caricatured as clowns who deserve to be scorned and ridiculed, and seen as prone to unhealthy dependencies, from drinking to gambling to philandering (Butsch, 2003; Leistyna \& Mollen, 2008). Blue-collar males fought with their partners, resorted to violence as a problem-solving device, plotted harebrained schemes, proved incompetent and often impotent, acted childish yet were inferior to their obviously smarter children, and displayed a look of bewilderment when challenged or chided. Butsch (2005, p. 115) captures a sense of the stereotyping at play in equating working-class folk as "uncouth, beer-bellied loudmouths, slovenly in appearance, couch potatoes, wife beaters, racists, and supporters of right-wing causes." In addition to being described as fat and thick, the working classes were rarely given credit for doing the dirty, tiring, and demeaning work that props up an affluent society, yet too often were blamed for societal problems over which they have little control (Leistyna \& Alper, 2005). And given the conflict of interest between management and labour, who can be surprised when the sharpest slings are reserved for unionized workers exposed as corrupt or lazy, and overwhelmingly responsible for labour unrest that costs or inconveniences (see Leistyna \& Alper, 2005)?

Nevertheless, media framing of working classes has proven confusing and inconsistent, and often contradictory. For the most part, two sets of masculinity tropes existed in the entertainment media:

1. Conventional hegemonic images of male masculinity prevailed. Privileging power as a determinant of masculinity ensured portrayals of heterosexual White males as strong, tough, disciplined, athletic, in control of self and others, stoic, providers for dependents, confidently secure and self-assured (but not cocky, boastful, or arrogant), virtuous at the core, and not openly superior or oppressive to others (Kusz, 2008). Yet the negative consequences of an übermasculine image could not be ignored. References and associations demonized males as inherently racist, sexist, and homophobic, with a worrying predilection toward aggression yet equally inclined to ineptness and flaccidity (Butsch, 2005). 
2. Stereotypes of the working-class "grunt" often conjure up images of unmotivated and unproductive shirkers who, as living relics of an industrialized past, are going nowhere (Working-Class Perspectives, 2008). No less salient is a salute to the dignity of blue-collar jobs as the physical labour and work ethic that enriches the country. From building cars to driving trucks, working-class jobs entail a resilience and toughness that few appreciate. For example, football commentators routinely praise football linemen as a "lunch bucket brigade" for "getting down and dirty" without complaint, while America's three major sports leagues (MBL, NBA, and NFL) claim solidarity with the American working man (Carroll, 2008).

Clearly, the dangers of over-generalizing the representational basis of television-working-class relations are all too real, thus providing a window of opportunity for media stories that commemorate the authenticity of real men. First, changes over time cannot be ignored: The working classes may have once been portrayed as the proverbial salt of the earth - hard-working, solid, sensible, honest, reliable, and open - whose trusting and straightforward naïveté could be milked for laughs (Manzoor, 2008). But this socalled naïveté is now reframed as working-class stupidity-a weakness to make fun of, especially by comparison to their upper-class superiors. Unlike media depictions of the middle classes as wise repositories of knowledge with impeccable tastes to boot, television depictions of working-class men in blue-collar occupations-from Archie and $\mathrm{Al}$ to Homer, Raymond, and George - typically reinforce counter-hegemonic images of blundering buffoons or the hopelessly baffled (Houpt, 2010; Palmer-Mehta, 2006). Second, internal variations are no less significant: In contrast to the largely negative framing of blue-collar workers is the positive onscreen treatment accorded those in professional working classes like police, nurses, and firefighters (Feasey, 2008; Malin, 2010). Third, gender differences must also be taken into account: Gender status is often inverted when working-class wives are portrayed as more intelligent and sensible than the putative head of the household and prime breadwinner. Accordingly, as Butsch (1992) argues, working-class males are demeaned and demasculinized by being depicted as childlike while their wives act as mother (authority) figures, in effect sowing the seeds for a televisual re-masculinizing of working men.

\section{Reclaiming a "muscular" masculinity: Toward a working-class heroic}

New trends are emerging that contest the representational bias of media-class relations. Partly in response to the decline of a key source of working-class masculinity - manual labour jobs (Carroll, 2008; Kimmel, 2010; Meltzer, 2010) - a slew of television shows frame working-class men as anything but doofus dads, leering ladies' men, and overgrown boys with more brawn than brain (Houpt, 2010). Indeed, they are depicted as heroic. The proliferation of extreme sports on film and television constitutes one example of re-masculinizing images of real men (Poulton \& Roderick, 2008). This observation is consistent with Desmond's (2009) prescient notion of a resurgent working-class cache, manifest in the wearing of traditionally working-class garb or consuming of working-class beer. According to Desmond (2009), "what we're experiencing in America today is a dual movement, the simultaneous erosion of blue-collar 
work and the adulation of blue-collar culture. Celebrating factory work renders the factory worker invisible" (p. 71).

This re-masculinization of blue-collar men is particularly evident in the genre of male docu soaps (Meltzer, 2010) that extols the masculine virtues and muscular accomplishments of manly working men. With its focus on the unsung heroism of the blue-collar worker, a new breed of reality-based shows is proliferating on cable, including Deadliest Catch, which is about Alaskan King crab fishing in the Bering Strait; $A x$ Men, about loggers in the northwestern forests of the United States; ${ }^{2}$ Ice Road Truckers, about transport in northern Canada and the United States; and Sandhogs, featuring miners under New York City. ${ }^{3}$

A focus on individualism, competition, risk-taking, and endurance reinforces the status of these shows as an offshoot of the unscripted television trend. Competitions among individuals or companies regarding how much work can be done over a certain time period and under conditions of duress are recurrent themes. For example, in Deadliest Catch there is a crab count that records the number of pounds of crab caught; in Ax Men a tally is kept of the number of loads of logs each company sends to the sawmill; and in Ice Road Truckers, the men compete over the number of loads transported. Narrators guide viewers through the shows. The film crews are on location, using a combination of static and handheld video cameras that enable them to get close to the action and capture workers' words and actions as they carry out their jobs. These filming techniques add to the sense of unscripted reality that the shows portray and bring the viewer closer to the action. There are replays of significant events, such as near accidents, and occasionally viewers are given descriptions of pieces of equipment or events using computer-generated images.

To analyze representations of masculinities in Deadliest Catch, Ax Men, Ice Road Truckers, and Sandhogs we examined the episodes from each program's seasons that aired between 2005 and 2010. Initially, a subset of episodes from each program were viewed and notes taken concerning the labour process (i.e., how the workers were deployed and what equipment was used), the settings where the work was carried out, and the narrative structure of the episodes. Then each episode was watched, this time with particular attention to the relations among workers and their employers, including the verbal and non-verbal interactions (e.g., practical jokes, teasing, horseplay), and the relationship between workers and their built and natural environment. Close attention was also paid to the types of behaviours that were rewarded and criticized and the consequences for those individuals who did or did not abide by workplace norms. While many recurring features of the shows provided important glimpses into how workingclass masculinity was constructed, certain aspects of the shows were particularly valuable for viewing the performance of masculinity. For instance, particular attention was paid to scenes and follow-up discussions related to injury or near misses, extremely intense and/or protracted work periods, and difficult work situations, such as mechanical breakdowns. From our textual analysis we derived seven major themes around the topic of heroism: underappreciated heroism, resiliency in the face of danger, dealing with risk of injury and fatality, masculinity as a product of perseverance, relative autonomy of manual work, the authenticity of hard manual labour, and camaraderie. ${ }^{4}$ 


\section{Heroism: Unsung providers}

In their own way each show discusses what important commodity or service they offer to society. In Sandhogs it is a tunnel for water. In Ice Road Truckers it is the materiel needed by northern communities and mines. These shows also reveal an unacknowledged or underappreciated importance in the services and commodities that these workers provide to the public. That is, while people are happy to consume what workers toil to produce, few consider the workers who are doing the jobs and what is entailed -including the risks - to do the work. For instance, at numerous points during Ax Men episodes we hear timber cutters and machine operators reflect on the fact that their hard and dangerous work creates the raw material for building homes and furniture.

The workers' heroism goes beyond the provision of goods and services for consumers, but extends to their status as providers for women and children. This theme is spliced into the narrative as the audience is given details about why and who the men are working for. Often we see that the men's decisions to persevere in the face of workplace challenges are partly influenced by their commitment to their family. On multiple episodes during season 3 of Ax Men, a greenhorn states that he endures the dangerous and gruelling work and the verbal abuse from his boss because he needs to support himself and his young son. Similarly, in Deadliest Catch, the deckhands and captains explain that their work enables them to provide for their families. Yes, they may be rugged and grizzly, with an unapologetically rough-hewn masculinity that disdains any softness as weakness. Yet they also come across as devoted family men and proud breadwinners who miss their wives and children as part of the price they pay for their work (Lockett, 2010; Meltzer, 2010).

\section{Danger: Risking it all by rising to the challenge}

Danger predominates in all of the shows. In reinforcing the common theme of man (men usually) against nature-a testing of one's masculinity in an epic struggle against the elements - men are exposed to bodily risks because of their natural environments. For the bearded and burly fishers on the Bering Sea in Deadliest Catch, the risk they face is the continual danger of injury or death from the unpredictable sea. At all times of year the men face the threat of storms that can swamp and sink a vessel or churn up swells that wash pitching decks with cold water, threatening to sweep crabbers off the deck. In winter, freezing temperatures are an additional hazard as wind-whipped spray turns to ice that accumulates on the ships and can cause them to capsize. For the loggers of $A x$ Men working on the slopes of northwestern U.S. mountain ranges, hazards lurk in the towering trees they fell, the runaway logs that tumble down hillsides, and the movement across steep, uneven, stick-strewn ground. And for the minors in Sandhogs, danger lurks in being hit by falling rocks, plummeting into the tunnels they excavate, and ceaselessly breathing particulate-filled air. The men of Ice Road Truckers continually confront danger in driving their rigs over frozen lakes (that double as roads) to deliver goods to remote mining sites and communities, while coping with sub-zero temperatures and whiteouts. Truckers must drive great distances for many hours at monotonously low speeds - 40 kilometres per houracross barren white landscapes, listening intently for the telltale cracks that warn of 
breaking ice. If a driver attempts to speed up, the risks increase - for getting a fine or breaking through the ice.

In all these shows production is heavily dependent on the successful operation of machinery that can be injurious or deadly. Well-functioning machinery that is used improperly by novice, careless, or fatigued operators puts both machine operator and surrounding workers at risk for injury. For instance, in an episode of Sandhogs, a veteran miner loses a finger to a machine. In numerous episodes of Deadliest Catch, a combination of rolling seas and inattention, inexperience, and exhaustion create the conditions in which standard safety procedures are deviated from and 700-pound crab pots slide across a boat's deck, either injuring or nearly missing a crabber.

Another set of hazards is posed by machinery malfunction. Regular operation of machinery over time will slowly wear out parts, causing breakdowns. In these television programs, the normal process of wear and tear on machinery is exacerbated by harsh environments and gung ho operators who want the most production out of their machines while incurring the least cost. When pushed to their limits, machine parts wear out or come undone, putting workers in danger. In multiple episodes of $A x$ Men, loggers scramble to avoid errant logs loosened by broken overhead lines. In Ice Road Truckers, a driver coaxes his truck along after it develops mechanical problems in minus 40 Celsius temperatures and he tries to avoid being stranded and risking frostbite.

As Meltzer (2010) points out, "Deadliest Catch, Ax Men, and Ice Road Truckers follow a conventional narrative structure: introduction of characters and setting, movement toward a climactic event and resolution" (p. 252). Within the episodes, as an integral part of "movement toward a climactic event," are scenes in which the spectacle of injury is presented visually and verbally as the characters often encounter pain and injury. These shows are fraught with frames depicting near misses, dodges, awkwardly twisting (and twisted) bodies, blood, and agony brought on by pain. Replays, narration, and close-ups all play a role in this drama. Often, these replays are followed by detailed commentary from the worker(s) involved. In one such case in Deadliest Catch, a crabber's quick actions enable him to avoid being hit by a crab pot. As the incident is replayed, a fellow deckhand remarks, "That's one of the ways you can go over the side of the boat right there. Unless you think quick and react quick, you will die, you can die." In a fashion analogous to media coverage of aggressive contact sports such as hockey and football (Messner, 1990; Trujillo, 2001), injuries, near misses, and close calls are repeated numerous times, dramatizing how a worker was injured or narrowly skirted injury or death. As a recurring feature of these shows, injuries sustained or nearly missed serve to reinforce the ideas that these workers courageously face dangers and that they possess skills that enable them to deftly avoid injury or death.

Dealing with risk of injury and fatality

How do these men confront the risk of injury and death in the course of their jobs? Workers describe being knowledgeable of the risks they face; nevertheless, they do not dwell on them, instead treating them as an accepted part of their job. This attitude is often portrayed when there are near misses: workers describe the incident, speak about how serious the injury could have been, and —unfazed—hurriedly return to 
work. In a sequence that similarly unfolds in other shows, a group of loggers in $A x$ Men barely escapes being hit by a log. They comment on the near miss, recounting how close they came to serious injury, and one says, "Everybody's had those little experiences ...," and finally, as the men go back to work, the narrator follows up, "The day's near miss won't stop this fearless crew from getting wood." The workers' awareness of the danger, together with their bravado in the face of it and willingness to quickly return to work, strengthens the image of these individuals as courageous.

When injuries do happen, the audience is treated to how they are dealt with. In most cases, injuries are treated as a normal and accepted part of work and employees toil on, working through the pain. A miner in Sandhogs, slowed by a painful shoulder injury, is told by a doctor to rest but disregards this counsel, returns to work, and dislocates his shoulder. This behaviour would seem immature in some settings but is lauded in this one, and the miner receives accolades for enduring the pain as his efforts ultimately enable the mining crew to press on.

Often, injuries of a minor nature are addressed by the injured party or with the assistance of fellow workers. For instance, in an episode of Deadliest Catch, a crabber, who has jammed his hand in the door of a crab pot and has a swollen finger is treated by the captain in the boat's galley. Under the captain's supervision, the crabber relieves the pain and pressure building underneath his fingernail by heating tweezers with a lighter and burning a hole through the nail. As the camera zooms in to capture the blood and ooze flowing from the pierced fingernail, the captain commends the crabber on his toughness. After a brief rest, the crabber is back on deck working. The crabber's return to work is typical of how men in these shows attempt to work through pain. The resiliency of the crabber signifies that he can endure pain like a man and continue to work.

In cases in which injury does happen or pain is present, toleration is stressed. Expressions of pain and injury are to be minimized unless the injuries are deemed by the men as severe. To act otherwise is to violate the norms of working-class masculinity. Not giving in to pain and injury is an important signifier that the workers are real men. This is similar to men dealing with pain and injury in sport (Vaccaro, 2011; Young, White, \& McTeer, 1994). As Young et al. (1994) point out, "[a]thletes who demonstrate pain or remove themselves from competition because of injury run the risk of being stigmatized by peers as less than fully masculine, particularly if the injury is not perceived as serious" (p. 190).

Although workers' abilities to work through pain are celebrated by fellow workers and those workers who are unable criticized, the very practices that males engage in to reach and remain at the top of the hierarchy in these types of settings may at the same time threaten their health (Donaldson, 1991; Wolkowitz, 2006). The dual influences of gender and class intersect in these shows through the work that the men do, and their health is threatened during their performances of masculinity and during their exchange of labour for wages. The workers in these shows are expected to partake in painful and injurious activities and endure in order to do their job. In this regard, they are very similar to elite athletes. Elite athletes demonstrate commitment to sport and masculinity by playing through pain and injury but at the same time damaging -in some cases irreparably_their bodies (Messner, 1990; Nixon, 1993). As Messner notes (1990), 
The instrumental rationality which teaches athletes to view their own bodies as machines and weapons with which to annihilate an objectified opponent ultimately comes back upon the athlete as an alien force: the body-as-weapon ultimately results in violence against one's own body. (p. 211)

\section{Maintaining gender order through perseverance}

Another theme that pervades the shows reinforces how these workers differ from everyday men, women, and boys. There are constant reminders that the work can only be done by men who are masculine enough to keep pace, endure pain that the job dishes out, and persevere in the face of long, arduous work hours. For instance, in $A x$ Men, when a greenhorn runs into problems unloading timber, a boss attributes his weak performance to the fact that he is a little boy and not yet a man. In an episode in season 1, Ax Men's narrator notes dramatically, "It's either time to give up or man up." The importance of workers' stamina in keeping up with the fast pace of work is also demonstrated in other work contexts. In Deadliest Catch, the boat crews' ability to fight fatigue is best seen when the crabbers are in the "grind," an onerous, monotonous setting, unloading, and resetting of crab pots that frequently lasts for 24 to 36 hours, with very little rest. Crabbers who cannot keep up are derided by both crew members and captains. Similarly, in Ax Men, workers are portrayed as running to logs to securely tether them to a line suspended overhead that quickly skids them from the bush. Failure to hustle is often met with yells of derision from fellow workers and supervisors. Sometimes, these are playful jabs; other times, they are commands that clearly highlight the power differences between supervisors and employees. Given that in most of these shows accomplishing work tasks is a collective endeavour, those who falter in "pulling their weight" are ridiculed by their workmates and superiors. Special amounts of disrespect are reserved for workers who desert their responsibilities.

In both Ax Men and Deadliest Catch, when workers leave the work site because they cannot endure the conditions, they are criticized by fellow workers and bosses. In Ax Men, an employer who confronts a rookie logger who failed to show up for work says, "You're acting like a puss, not a man. A man goes to work and does his job! A puss sits at home and [bleep] pulls it ... And you're just [bleep] pulling it." When a greenhorn quits after only a day on a crab boat, the captain says he was a "quitter" who "couldn't handle the job" and the quitting prompts a fellow rookie to say, "He didn't even last 24 hours! Come on - you can do anything for 24 hours!" For the truckers on the ice roads, endurance is the ability to keep making runs long after becoming fatigued. They pride themselves on the ability to ceaselessly "turn and burn": the practice of driving for hours delivering a load and quickly picking up a new one to haul to another destination. For the authentic ice-road trucker, rest, it would seem, is left to the non-hackers.

Autonomy of workers, authenticity of work

There is much talk among the workers in these programs about the freedom of their work. One way in which freedom is depicted is spatially. In Deadliest Catch, Ax Men, and Ice Road Truckers, we are reminded that the work being carried out is not in the concrete confines of the city. Viewers are privy to expansive vistas of the Bering Sea 
and Alaskan coast in Deadliest Catch. As a log truck driver in Ax Men notes, motioning to the window of his truck, "Nice view from my office," as the camera pans over an unpopulated, heavily forested, steeply sloped valley. In this case, the frontier dimension not only repudiates the urban in defining this work as autonomous and authentic, but also helps to construct a kind of masculinity that engages nature by taming it (see also Hogan \& Pursell, 2008). This idealization of working-class masculinity as an authentic masculinity both unalloyed and unmediated is best put to the test at geographical extremes such as the Arctic or the Bering Sea, thus redramatizing the mythic (frontier) struggle between men and untamed wilderness (Lockett, 2010; Meltzer, 2010).

Another way that freedom is portrayed in these shows is through differences in the rules that govern these frontier workplaces. In emphasizing an inextricable connection of real work with geography (especially frontier realms or wilderness landscapes) (Hogan \& Pursell, 2008), the shows highlight how blue-collar males are able to escape the constraints that entrap those confined in the knowledge economy and service sector. In the words of a cutter in Ax Men, the loggers are not plagued by the problems of the "rat race." Even when the television shows are not outside in the wilderness, such as Sandhogs, they highlight the distance between "us" and "them." The miners featured in Sandhogs work beneath one of the busiest cities in the world, but their work underground affords them distance from the rules of everyday work in the knowledge economy.

Running through the shows is the idea that "out here," or in the case of Sandhogs "down here," it is a different place, one that is free from the petty tyrannies of the office, such as dress codes, proper comportment, and manners. It is a place where hard work is celebrated and men can act in a manly manner. And in many ways they do: there is cursing, yelling, idle threats, altercations, horseplay, and practical jokes, all of which are behaviours that are present in male-dominated working-class settings (Collinson,1988; Desmond, 2007; Gregory, 2006; Iacuone, 2005; Paap, 2006).

Indeed, an important part of establishing and maintaining masculinity is that men have the "space" to act as authentic men who do not have to subordinate their masculinity to a set of rules that others - women and subordinate masculinities - have constructed and that they have to abide by (Paap, 2006). This space, free of constraints, can be contrasted with the emotional labour that is expected of interactive service workers in the post-industrial economy, who must control their own emotions, promote certain emotions defined by an organization, and manage the emotions of customers or clients (Nixon, 2009). The space that blue-collar workers have insulates them from encroaching political correctness that threatens working-class masculinity.

Of course, as Desmond (2007) notes, this "freedom" does not amount to an absence of rules but rather represents a different set of rules, in this case hegemonic masculinity, that governs a work subculture. Failure to play by the rules can be met with derision by others and lead to an erosion of masculinity. In his study set in an automotive manufacturing plant, Collinson (1988) noted, "Manual workers were required to display a willingness, for example, to give and take a joke, to swear, to be dismissive of women, and to retain their domestic authority" (p. 197). Because men in such work settings are expected to respect working-class masculine norms and risk censure for 
violating them, they in effect escape the entrapment of one set of rules- those of the office - and are ensnared in another-those of hegemonic masculinity.

Autonomy is also a product of the workers' independence. Of particular note is the value attached to the dignity of manual competence within the context of a constructed material world where a person can feel like a man rather than a cog in the machine (Crawford, 2009). The workers' self-sufficiency is touted as critical to independence, as the men are frequently in positions in which calling for assistance is not an option because of unacceptable production stoppages. This resourcefulness is highlighted when machinery breaks down and workers are forced to improvise by using the materials at hand. During multiple episodes of Ax Men, when the overhead cables critical to retrieving timber break and logging comes to a halt, loggers crudely repair the cables to get the crew operational again. In Deadliest Catch, on several occasions, mechanical aptitude and courage are seen as crew members climb aloft in pitching seas to fix broken cranes critical to fishing.

Self-reliance can be achieved not only through ingenuity. It is also connected to the competency of avoiding unnecessary problems that hinder production. The connection between competence and self-reliance is brought into sharper relief when workers misuse or incorrectly use equipment and this creates slowdowns in production. These lapses are especially apparent among novices on the shows. These workers suffer doubly: they are prevented from achieving their goals and they are derided by their fellow workers and bosses. In Ice Road Truckers, a rookie ice-road driver is ridiculed by both his boss and fellow drivers for repeatedly bringing his truck into a mechanic for problems they deem avoidable. He suffers the ultimate indignation among ice-road drivers as he quits pulling loads on the treacherous ice roads and delivers goods within a city.

The competence that the men display symbolizes their ability to control reluctant or seemingly inoperable technology. Their ability to be action-oriented rather than victims of circumstance reinforces their competence as agents of their fate. Further, it demonstrates independence - that an individual or small band of men can work through problems with little or no outside assistance (Desmond, 2007; Thurnell-Read \& Parker, 2008).

\section{Esprit de corps: Competition in camaraderie}

Despite the virtues of individualism and autonomy, notions of camaraderie and "mateship" are prominently featured. In some of the programs, terms such as "brotherhood" are used to describe the relationships between workers who generally work in small groups. At times, it is difficult to discern who has the most seniority or who is in charge. This is akin to firefighting fraternity or team sport conviviality, where members look out for one another. In all the shows there are examples of playful jousting, belittling, and disagreements; nevertheless, workers come together to get the job done and frequently note the tight bonds among them. As a timber cutter from Ax Men points out, "We pick at each other.... But don't try to get between us." Moreover, because of the way Ax Men, Deadliest Catch, and Ice Road Truckers are set up as competition among companies, another layer of competition exists among the men in working hardest and earning most. For example, in Ice Road Truckers, annual competitions determine 
who has made the highest number of runs during the two-month ice-road season. Rarely do we see the tensions that pervade many workplaces-namely, workers' battles with management or employers - and when we do, these tensions are often depoliticized: they are depicted as one or two recalcitrant workers resisting a stubborn boss's direction. Just as Carroll (2008) notes in his examination of the program American Chopper, the characters in Ax Men, Deadliest Catch, Ice Road Truckers, and Sandhogs portray the working class and celebrate their work, but there is little attempt to connect with the working class at the level of class consciousness.

\section{Contesting masculinities: Tough guys as "tough guise 5" $^{\text {" }}$}

This article contends that a new breed of unscripted shows about working-class heroism constitutes a trend toward re-masculinizing males through the prism of their working-class lives (see Carroll, 2008). Whether it is Ice Road Truckers, Deadliest Catch, Ax Men, or Sandhogs, the theme is unmistakably similar: the resuscitation of blue-collar authenticity through the bravery and courage of real "macho" men in risky occupations, battling the forces of nature, co-workers and managers, and themselves. Membership in muscular working-class masculinity not only provides a source of pride, self-esteem, and control; it also provides an embodied male proving ground secured along the lines of three activities - not being characterized as feminine, seeking approval of other men, and banding together with other men (Kimmel, 2010). In that embodiment is embraced as an authentic component of masculinity (McDowell, 2003), disdain and antipathy are directed at the contrived masculinity of white-collar workers, whose disembodied rationality in emotional/mental labour clashes with an embodied working-class habitus (Nixon, 2009; also Crawford, 2009). In his study of working-class men's perceptions of interactive service-sector jobs, Nixon (2009) notes,

The men rejected female-dominated interactive service occupations that involved high amounts of emotional labour because they struggled to manage their emotions and be passive and deferential within the service encounter and because such work denied them the opportunity to relieve their stress in their usual ways - through shouting, swearing, taking the piss and having a laugh. (pp. 318-319)

Clearly, then, participation in the working-class heroics of power, control, and authority removes the fear of being feminized (Mumby, 1998; Nixon, 2009). Understanding the logic behind these docu soaps necessitates their placement in the broader context of shifting gender relations. In threatened response to changes in the social, cultural, and employment context where physicality no longer defines women and men, as Katz and Jhally (2000) assert, there is a retreat into the muscular masculinity of a more primal gender order that reinforces patterns of power and control through size and strength. Just as men's experiences draw upon cultural beliefs related to social class, so too are they deeply gendered with respect to ideas and ideals about masculinity (Hill, 2004).

In short, any pretext to a mediated hegemonic masculinity has been contested in recent years. With the erosion of male cultural norms and social authority, media de- 
pictions of a hegemonic masculinity that privileged a dominant way of "doing men" (Hirose \& Pih, 2010, p. 193) confront newer masculinities seemingly more consistent with feminist and gay agendas (Hanke, 1992, 1998a). The end result is nothing short of catastrophic in massaging the message of manliness, namely, a mounting identity crisis for working- class folk ("who are we"), with a corresponding crisis of confidence ("what should we be doing, and how") (see also Katz \& Jhally, 1999). This crisis in masculinity is aptly captured by Giroux (2001):

White, heterosexual men in America did not fare well in the 1990s. Not only have they been attacked by feminists, gays, lesbians and various subaltern groups for a variety of ideological and material offenses, they have also had to endure a rewriting of the very meaning of masculinity. (p. 7)

A similar theme is pursued by Susan Faludi in her book Stiffed (1999). The betrayal of American men reflects the decline in traditional masculine jobs (e.g., manufacturing, construction) with deep-seated insecurities about their pending emasculinization. Working-class males are experiencing an identity crisis of confidence because of socioeconomic changes not of their own making, increasingly anxious in a world where being a breadwinner and making ends meet is hardly a foregone conclusion and increasingly confused by new demands about emotional responsiveness (Kimmel, 2010). The representational crisis in masculinity exerts pressure to reassert virility and manliness - if only at fantasy levels - to compensate for the ambiguities of living in a real world of diminished independence and control over life chances (Fine, Weis, Addleston, \& Marusza, 1997; Fiske, 1987; Hodkinson, 2011; McDowell, 2003). The putative restoration of a "muscular" masculinity is conveyed by Gordinier (2010) when he explains,

After years of dutiful, dues-paying obsequiousness, men seem to be coming to the realization that surviving (and [e]ven enjoying) the wide-open Wild West gestalt of 2010 demands a different response than testicular retraction. In other words, we're witnessing the remasculation of the American man. (p.1)

Insofar as all masculinities are not created equally or have equal value, but are subject to negotiation, change, and redefinition (Connell, 2005; Kimmell, 2010), new media frames are pivotal in constructing and reviving manly masculinities without explicitly declaring an all-out cultural war (Carroll, 2008; Hogan \& Pursell, 2008; Kusz, 2008). One strategy is to code working males as conventionally masculine, including the construction of violent masculinity as a cultural norm (Katz \& Jhally, 1999; Messner, 1990), with a corresponding list of traits diametrically opposed to those of the metrosexualized new age guys (see Houpt 2010; Vincent, 2008). The valorization of the ordinary, real, and authentic in contrast to the liberal and elite is expressed through action, not symbolic work (Lockett, 2010). Another strategy is to juxtapose these masculinized images with those of affluent white (collar) males and feminized metrosexual men, upon which feminism and political correctness are negatively projected and vicariously played out. For example, in his book Shop Class as Soul Craft (2009), Crawford demonstrates how knowledge workers are sharply rebuked for employment in repetitious, creativity-killing tasks whose autonomy is compromised by management. Yet another 
strategy is to depict these masculinized males as simultaneously marginalized and disadvantaged, in contrast with those unmanly men who embody wealth and privilege, yet who kowtow to the establishment, are linked to questionable money-making schemes, or engaged in emotional labour.

\section{Conclusion: Rethinking the heroic}

A new form of television show portrays working-class men in a very different light: heroic. In doing so it draws on selective symbols of hegemonic masculinity and reproduces them. These shows reproduce a white gender order under a "tough new guise" (Leistyna \& Alper, 2005) that (1) celebrates working-class men as heroic, (2) reaffirms aspects of hegemonic masculinity, (3) uncritically whitewashes reality. Kusz (2008) writes, "these seemingly 'different' white male protagonists paradoxically function to reproduce white American patriarchy even as they appear, on first glance, to be distanced and disaffiliated with it" (p. 99).

The appeal of these unscripted shows is striking. Their popularity may reflect a combination of awe and beauty inspired by the work environment, together with the moxie, mettle, and skill of the men in coping with the destructive forces of nature. In conveying a nostalgia for fictional frontier myths and wilderness tamed by heroic masculinity, these shows depoliticize and gender the working-class characters, thus allowing audiences to vicariously engage with the masculine adventure and working-class drama without having to deal with messy issues of job security, fair wages, or health and safety (Kimmel, 2010; Lockett, 2010; Meltzer, 2010). In particular, the men sacrifice their health to earn a living and simultaneously derive a source of masculinity from their work (Donaldson, 1991; Paap, 2006; Wolkowitz, 2006). As well, the appeal of these shows reflects their dramatic effect, especially in terms of conflict or pending disaster - an effect partly achieved by editing out the mundane and boring aspects of the jobs (Meltzer, 2010), thus embellishing them with more peril and adventure than they typically feature in reality (Turner, 2010).

A sense of perspective is critical. At their best, these shows highlight the difficult work and sacrifices made by working-class men so that the affluent can revel in the good life. At their worst, these shows - in their attempts to valorize the working-class heroic by escaping into fantasy-gloss over too much of the men's working lives. Notwithstanding some focus on the suffering and sacrifices of workers, the shows do little to contextualize deprivation, risk-taking, or ill health, much less to explain the causes of these hardships in structural rather than individualistic terms.

Typically, these television shows present work hazards as an individual, technical, or environmental problem; they exclude sources of injury that are social or political (e.g., relations of production and state regulation). That these occupations are dangerous is not in dispute. Transportation, forestry, and commercial fishing rank as some of the most hazardous industries in North America (Krahn, Lowe, \& Hughes, 2007). However, in television's attempts to valorize "dangerous jobs" and the men that do them, what is omitted reflects a medium that entices viewers with stories that shock but ultimately may misrepresent the totality of workers' experiences. As a result, workers' experiences with injury, work hazards, and near misses reinforce a medium's predilection to use material appealing to viewers but concomitantly to understate exposure to other 
occupational health problems that are acquired over time through overuse and/or awkward work positions, such as carpal tunnel syndrome or back injuries (Bonauto, Silverstein, Adams, \& Foley, 2006; Lyons, 2002; Palmer, Harris, \& Coggon, 2007). Though less exciting, these health hazards may be equally or more devastating than those described and shown to viewers.

The irony is no less inescapable: The onscreen presentation of blue-collar work privileges manual labour at precisely the moment this kind of work is disappearing. This valorization of working-class experiences and culture expresses itself in the macho masculinity of skilled manual labour that constructs a nostalgic world of bluecollar work in which male manual labour still prevails, largely untouched by the nouveau masculinities engendered by the post-civil-rights era and post-industrial service economy (Carroll, 2008). And yet that working-class masculinity that celebrates the muscular manliness of manual labour is far from being supplanted by alternative forms of mediated masculinity. This new turn in televising masculinity serves as a reminder that "[i]t is important not to overemphasize or romanticize the subversive potential of alternative representations, on one hand, and to underestimate the resilience of hegemonic modes of masculinity on the other" (McKay, Mikosza, \& Hutchins, 2005, p. 284).

Clearly, then, this heroic narrative is not what it always seems to be. As Desmond (2008) points out in debunking the hypocrisy of labelling wildland firefighters as heroes, there are two ways to dehumanize: either strip people of all virtue or cleanse them of all sin. Heroicizing workers in risky occupations has had the effect of flattening their humanity, with the result that they are elevated to the status of mythic creaturesnoble, virtuous, manly - whose sacrifices ensure a comfortable standard of living for the population at large. This worker as unsung hero also performs ideological work insofar as the mythology conceals how the blue-collar working class as professional risk-takers generate wealth for those who own or control. This fact alone makes it doubly important to deconstruct the label of heroism when applied to those working-class labourers who toil in the remaining blue-collar jobs.

\section{Notes}

1. "Framing" refers to the process of organizing media information by drawing attention to some aspects of reality as normal, desirable, or acceptable, while drawing attention away from other aspects perceived as inferior, irrelevant, or threatening. Frames intend to encourage a preferred reading as if it were natural and uncontested rather than constructed and unproblematic, thereby drawing audiences into "seeing like the media," as if this framing lacked any perspective or bias (Fleras, 2011).

2. Ax Men has come to feature loggers in several contexts. In the program's inaugural season, the primary focus was on northwestern loggers in mountainous terrain and one group of loggers who were salvaging logs from a river. In later seasons, the contexts have expanded to include heli-logging and logging in the swamps of Louisiana. For the purpose of this article, we concentrate on those loggers in the forests of the northwestern United States.

3. These programs are popular-at least judging by their ratings. Highlighting the fact that some of these shows have gone beyond niche markets, cast members of one, Deadliest Catch, have been interviewed on national talk shows. As of 2010, this show was into its sixth season, Ice Road Truckers into its fourth, and Ax Men into its third (see Keveney, 2008). These shows have spawned many similar series, such as Lobster Wars, American Loggers, Swords: Life on the Line, Licence to Drill, and Ice Pilots. The inaugural episode of Ice Pilots "attracted 459,000 viewers, an unusually large number for a cable series" 
("Ice Pilots NWT a hit," 2009). Typically, these programs are supported by interactive websites that allow a viewer to learn more about the specific equipment used by workers, about the workers themselves, and about the industry. Several of the websites also enable people to watch full episodes, download episodes to their computers, or offer the option of purchasing seasons of the program on DVD. Fans of the television shows can purchase memorabilia such as baseball hats and T-shirts with the program's logo (see also Meltzer, 2010).

4. The workplaces featured in these shows are staffed predominantly by men. In two shows, Ice Road Truckers and Deadliest Catch, women are employed. In seasons 3 and 4 of Ice Road Truckers, a woman is one of the show's star truck drivers. In Deadliest Catch, only occasionally do we see women on board crab boats and only rarely do women appear on deck.

5. See Jhally, Katz, \& Earp, 1999.

\section{References}

Aguiar, Luis L. M. (2005). Cleaners and pop-culture representation. Just Labour, 5, 65-79.

Benson, Rodney. (2005). American journalism and the politics of diversity. Media, Culture \& Society, 27(1), 5-20.

Bonauto, David, Silverstein, Barbara, Adams, Darrin, \& Foley, Michael. (2006). Prioritizing industries for occupational injury and illness prevention and research: Washington State workers' compensation claims, 1999-2003. Journal of Occupational \& Environmental Medicine, 48(8), 840-851.

Bruce, Jean. (2009). Home improvement television: Holmes on Homes makes it right. Canadian Journal of Communication, 34, 79-94.

Butsch Richard. (1992). Social class and television. Chicago, IL: Museum of Broadcast Communication. URL: http://www.museum.tv [December 8, 2011].

Butsch, Richard. (2003). Ralph, Fred, Archie, and Homer: Why television keeps re-creating the white male working-class buffoon. In Gail Dines \& Jean Humez (Eds.), Gender, race, and class in media: A text-reader (2nd ed.) (pp. 575-585). Thousand Oaks, CA: Sage.

Butsch, Richard. (2005). Five decades and three hundred sitcoms about class and gender. In Gary Edgerton \& Brian Rose (Eds.), Thinking outside the box: A contemporary genre television reader (pp. 111-135). Lexington, KY: University Press of Kentucky.

Carroll, Hamilton. (2008). Men's soaps: Automotive television programming and contemporary working-class masculinities. Television \& New Media, 9(4), 263-283.

Collinson, David L. (1988). 'Engineering humour': Masculinity, joking and conflict in shop-floor relations. Organization Studies, 9(2), 181-199.

Connell, R. W. (2005). Masculinities. Cambridge, UK: Polity Press.

Connell, R. W., \& Messerschmidt, J. W. (2005). Hegemonic masculinity: Rethinking the concept. Gender \& Society, 19(6), 829-859.

Crawford, Matthew B. (2009). Shop class as soulcraft: An inquiry into the value of work. New York, NY: Penguin Press.

Croteau, David, \& Hoynes, William. (2003). Media/Society: Industries, images, and audiences (3rd ed). Thousand Oaks, CA: Sage.

Desmond, Mathew. (2007). On the fireline: Living and dying with wild land firefighters. Chicago, IL: University of Chicago Press.

Desmond, Mathew. (2008). The lie of heroism. Contexts, 7(1), 56-58.

Desmond, Mathew. (2009). Bottoms up. Contexts, 8(1), 69-71.

Donaldson, M. (1991). Time of our lives: Labour and love in the working class. Sydney: Allen \& Unwin.

Dummit, Christopher. (2007). The manly modern: Masculinity in postwar Canada. Vancouver, BC: UBC Press.

Faludi, Susan. (1999). Stiffed. The betrayal of the American man. New York, NY: Perennial.

Feasey, Rebecca. (2008). Masculinity and popular television. Edinburgh: Edinburgh University Press.

Fine, Michelle, Weis, Lois, Addelston, Judi, \& Marusza, Julia. (1997). (In)secure times: Constructing white working-class masculinities in the late 20th century. Gender and Society, 11(1), 52-68.

Fiske, John. (1987). Television culture. London: Methuen 
Fleras, Augie. (2011). The media gaze: Media representations of diversities in Canada. Vancouver, BC: UBC Press.

Giroux, Henri. (2001). Private satisfactions and public disorders: Fight Club, patriarchy, and the politics of masculine violence. Journal of Advanced Composition, 21(1), 1-31.

Gordinier, Jeff. (2010, March). The remasculated man. Details. URL: http://www.details.com/culture -trends/critical-eye/201003/remasculated-man .

Gregory, Chad. (2006). Among the dockhands: Another look at working-class male culture. Men and Masculinities, 9(2), 252-260.

Hackett, Robert A., \& Gruneau, Richard. (2000). The missing news: Filters and blindspots in Canada's press. Aurora, ON: Canadian Centre for Policy Alternatives.

Hanke, R. (1992). Redesiging men: Hegemonic masculinity in transition. In S. Craig (Ed.), Men, masculinity, and the media (pp. 185-198). Newbury Park, CA: Sage.

Hanke, Robert. (1998a). Theorizing masculinity with/in the media. Communication Theory, 8(2), 183-201.

Hanke, Robert. (1998b). The "mock-macho" situation comedy: Hegemonic masculinity and its reiteration. Western Journal of Communication, 62(1), 74-93.

Henry, Frances, \& Tator, Carol. (2002). Discourses of domination. Toronto, ON: University of Toronto Press.

Hill, Patricia Collins. (2004). Black sexual politics: African Americans, gender, and the new racism. New York, NY: Routledge.

Hirose, A., \& Pih, K. K . (2010). Men who strike men who submit: Hegemonic and marginalized masculinities in mixed martial arts. Men and Masculinities, 13(2),190-209.

Hodkinson, Paul. (2011). Media, culture, and society: An introduction. Los Angeles, CA: Sage.

Hogan, Maureen P., \& Pursell, Timothy. (2008). The "Real Alaskan": Nostalgia and rural masculinity in the "Last Frontier." Men and Masculinities, 11(1), 63-85.

Houpt, Simon. (2010, February 12). Blowing the whistle on men's marketing. The Globe and Mail, p. B6. Hutcheon, Linda. (2009, July/August). Reviewing reviewing today. Literary Review of Canada, 1-7.

Iacuone, David. (2005). Real men are tough guys: Hegemonic masculinity and safety in the construction industry. Journal of Men's Studies, 13(2), 247-266.

Ice Pilots NWT a hit. (2009). The Globe and Mail, p. R4.

Jhally, Sut, Katz, Jackson \& Earp, Jeremy (Director/Writers). (1999). Tough guise: Violence, media and the crisis in masculinity [Documentary]. Northhampton, MA: Media Education Foundation.

Katz, Jackson. (1999, Spring). Men, masculinities, and media: Some introductory notes. WCW Research Report, 16-17.

Katz, Jackson, \& Jhally, Sut. (1999, May 2). Crisis in masculinity. The Boston Globe.

Katz, Jackson, \& Jhally, Sut. (2000, February 23). Manhood on the mat. The Boston Globe.

Kellner, Douglas. (1995). Media culture: Cultural studies, identity and politics between the modern and the post-modern. New York, NY: Routledge.

Kendall, Diana. (2005). Framing class: Media representations of wealth and poverty in the United States. Lanham, MD: Rowman \& Littlefield.

Keveney, Bill. (2008, March 21). Dangerous ‘Ax Men' has a real edge. USA Today, p. 7E.

Kimmell, Michael. (2010). Misframing men: The politics of contemporary masculinities. Piscataway, NJ: Rutgers University Press.

Krahn, H. J., Lowe, G. S., \& Hughes, K. D. (2007). Work, industry and Canadian society (5th ed.). Scarborough, ON: Thomson Nelson.

Kusz, Kyle. (2008). Remasculinizing American white guys in/through new millennium American sports films. In E. Poulton \& M. Roderick (Eds.), Sport in films (pp. 93-110). New York, NY: Routledge.

Leistyna, Pepi, Alper, Loretta (Co-writers \& Producers). (2005). Class dismissed: How TV frames the working class [Documentary]. Available from Media Education Foundation, Northampton, MA.

Leistyna, Pepi, \& Mollen, Debra. (2008). Teaching social class through alternative media and by dialoguing across disciplines and boundaries. Radical Teacher, 81(1), 20-27.

Lockett, Christopher. (2010). Masculinity and authenticity: Reality TV's real men. Posted by C. Lockett, Memorial University. URL: http://flowtv.org/2010/10/masculinity-and-authenticity . 
Lyons, Jane. (2002). Factors contributing to low back pain among professional drivers: A review of current literature and possible ergonomic controls. Work: A Journal of Prevention, Assessment and Rehabilitation, 19(1), 95-102.

Malin, Brenton J. (2010). Viral manhood: Niche marketing, hard-boiled detectives, and the economics of masculinity. Media, Culture \& Society, 32(3), 373-389.

Mantsios, Gregory. (2001). Media magic: Making class invisible. In Paula Rothenberg (Ed.), Race, class, and gender in the United States (5th ed.). (560-568) New York, NY: Martins.

Manzoor, Sarfras. (2008, March 3). The Forgotten People. The Guardian (Manchester). URL: http://www.guardian.co.uk . [December 12, 2011].

Mazzarella, Sharon R. (2008). Men, media, and machines: Fabricating masculinities in American Chopper. Popular Communication, 6(2), 68-84.

McDowell, Linda. (2003). Redundant masculinities? Employment change and white working class youth. Malden, MA: Blackwell Publishing.

McKay, J., Mikosza, J., \& Hutchins, B. (2005). "Gentlemen, the lunchbox has landed": Representations of masculinities and men's bodies in the popular media. In Michael S. Kimmel, Jeff Hearn, \& Raewyn Connell (Eds.), Handbook of studies on men and masculinities (pp. 270288). Thousand Oaks, CA: Sage.

Meltzer, Kimberly. (2010). A different sort of reality TV hero: Extreme fishermen, loggers and truckers on the edge. In Lemi Baruh \& Ji Hoon Park (Eds.), Reel politics: Reality television as a platform for political discourse (pp. 249-264). Cambridge, UK: Cambridge Scholars Publishing.

Messner, Michael A. (1990). When bodies are weapons: Masculinity and violence in sport. International Review for the Sociology of Sport, 25(3), 203-220.

Mulvey, Laura. (1975). Visual pleasures and narrative cinema. Screen, 16(3), 6-18.

Mumby, Dennis K. (1998). Organizing men: Power, discourse, and the social construction of masculinity(s) in the workplace. Communication Theory, 8(2), 164-183.

Nixon, Darren. (2009). 'I can’t put a smiley face on': Working-class masculinity, emotional labour, and service work in the 'new economy.' Gender, Work, and Organization, 16(3), 300-321.

Nixon, H. L. (1993). Accepting the risks of pain and injury in sport: Mediated cultural influences on playing hurt. Sociology of Sport Journal, 10(2), 183-196.

Paap, Kris. (2006). Working construction: Why white working-class men put themselves - and the labor movement-in harm's way. Ithaca, NY: Cornell University Press.

Palmer, Keith T., Harris, E. Clare, \& Coggon, David. (2007). Carpal tunnel syndrome and its relation to occupation: A systematic literature review. Occupational Medicine, 57(1), 57-66.

Palmer-Mehta, Valerie. (2006). The wisdom of folly: Disrupting masculinity in King of the Hill. Text and Performance Quarterly, 26(2), 181-198.

Poulton, Emma, \& Roderick, Martin. (2008). Introducing sport in films. Sport in Society, 11(2-3), 107-116.

Thurnell-Read, Thomas, \& Parker, Andrew. (2008). Men, masculinities and firefighting: Occupational identity, shop-floor culture and organisational change. Emotion, Space, and Society, 1(2), 127-134.

Trujillo, Nick. (2001). Machines, missiles and men: Images of the male body on ABC's Monday Night Football. In Andrew Yiannakis \& Merrill J. Melnick (Eds.), Contemporary issues in sociology of sport (pp. 223-236). Champaign, IL: Human Kinetics.

Turner, James (2010, February 21). The workplace (as seen on TV). Christian Science Monitor, 102(13), 3-5.

Vaccaro, Christian Alexander. (2011). Male bodies in manhood acts: The role of body-talk and embodied practice in signifying culturally dominant notions of manhood. Sociology Compass, 5(1), 65-76.

Vincent, Norma. (2008). Self-made man. London: Atlantic Books.

Winter, James. (2001). Media think. Montréal, QC: Black Rose Books.

Wolkowitz, Carol. (2006). Bodies at work. Thousand Oaks, CA: Sage.

Working-Class Perspectives (2008, September 8). Stereotyping the working class. URL: http:// workingclassstudies.wordpress.com .

Young, Kevin, White, Phillip, \& McTeer, William. (1994). Body talk: Male athletes reflect on sport, injury, and pain. Sociology of Sport Journal, 1, 175-194. 
